\title{
浦添ようどれの石棺にみられる建築表現と王陵の変遷 \\ THE DEVELOPMENT OF IMPERIAL MAUSOLEUM OF THE RYUKYU DYNASTY, URASOE YODORE: ICONOLOGICAL ANALYSIS OF SCULPTURES ON THE STONE COFFINS
}

\author{
高屋 麻里子* \\ Mariko TAKAYA
}

\begin{abstract}
Urasoe Yodore is known as the oldest imperial mausoleum of the Ryukyu Dynasty. The mausoleum has two tombs, "King Shonei's tomb" and
"King Eiso's tomb". There are stone coffins, sculptured in the form of buildings.

From analysis of the architectural sculpture on the stone coffins, they can be dated to around the Kamakura period. The coffins are sculptured in the form of the interior of a hall of Buddhist stupa or temple.
\end{abstract}

The construction of Urasoe Yodore is divided into 3 periods.

Architectural characteristics appeared on the coffins show influences from China, Korea and Japan.

Keywords: Urasoe Yodore, Ryukyu Dynasty, Stone coffin, Relief sculpture, Kumimono, Buddhism image 浦添ようどれ、琉球王朝、石棺、彫刻、組物、仏像

\section{1. はじめに}

琉球の王陵は、第二尚氏の造営による玉陵(たまうどうん)が知ら れているが、第一尚氏以前からの造営と考えられている王陵が浦添 ようどれである。浦添ようどれには二つの募室があり、それぞれに 王の名が冠されている。東側が第二尚氏第七代の尚寧王陵とされる。 西側は、第一尚氏以前、擦度王統の前、1299年に浦添極楽山に葬 られた英祖王の墓と伝えられ、英祖王陵と呼ばれる。

浦添ようどれには、四基の輝緑凝灰岩製大型石棺、二基の小型石 棺が現存している 建物礎石とみられる石が配されていること、高度な加工がされた金 具、高麗系瓦などが発見され、戦前まで知られていた形態が本来の ものではなかったことが判明している゙21。

しかし、浦添ようどれの変遷過程を示す史料としては、発掘成果 と石棺、浦添ようどれに残る尚寧王が作成したとされる碑文に限ら れている。また、第二尚氏時代以前の建築で、現存している遺構は 知られていないので、浦添ようどれの石棺は、現存知られているな かでは最も古い時代に属する建築史料でもある。本論文では石棺の 建築表現からこれが製作された時期を考察し、浦添ようどれの変遷 を明らかにすることを試みる。

浦添ようどれの石棺と王陵に関しては、2003年9月に写真記録
と英祖王陵内の実測調查を行い、他の王陵に関する見学調查は2004 年3月に行った ${ }^{\text {\#3 }}$ 。1973年の又吉真三氏の実測調査記録断を用い、 その他の石棺については『重要文化財 玉陵復原修理工事報告書』 注のを史料とする。

\section{2. 浦添ようどれの石槴}

\section{2-1. 建築史料としての石棺}

彫刻や陶製家型模型などから、現存しない建築の形態を得る試み は、例えば中国古代の木造建築の痕跡を求めて広く行われている。 特に、漢代の副葬品として知られる明器などが、古代の木造家屋の 形態を知る手がかりとされている。また、石窟寺院などに残された、 木造と考えられる部材表現などから、該当する時代の木造建築の形 態を推測し、日本の同時代の建築への影響も論じられている ${ }^{\text {itの。 }}$

また、日本では石造の家型墓標などが、日本海側各地に分布して いることが知られてはいるが、独立した建築物としての扱いにとど まり、現存する建築との関係を広く論じられてはいない清》。石造家 型石棺に対しては主に彫刻表現や工芸品、美術品としての価値に関 心がむけられ、建築表現が論じられることは少ない。

\section{2-2. 石棺の建築表現と表現対象}

* 千葉大学大学院自然科学研究科人間・地球環境科学専攻 博士後期課程・修士 (工学)
Graduate Student, Graduate School of Science and Technology, Chiba University, M. Eng. 


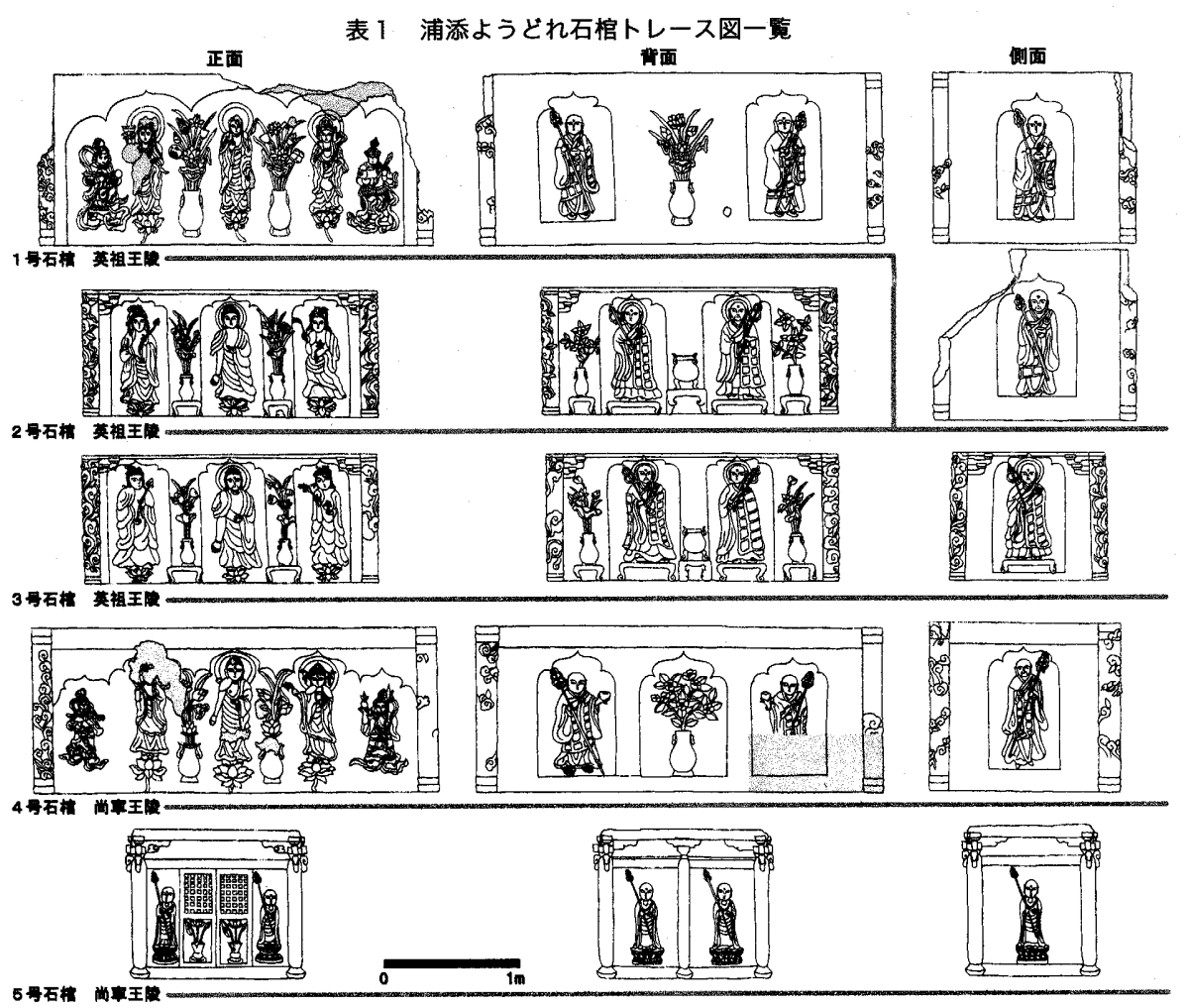

浦添ようどれをはじめとする石製蔵骨器については、形状から石 欴子と表記されることも多いが、本論文では、国子が仏舎利容器を 指すこと、後に仏堂内で仏像を納めるものを指すことから、区別す る意味で棺ととらえ、石製のものを石棺と表記する。

浦添ようどれの石棺名称は、英祖王陵内の 1 号から 3 号、尚寧王 陵の 4 号から 6 号とする ${ }^{* 88}$ 。因 1 に尚寧王陵と英祖王陵の平面図と 石棺の配置を示す ${ }^{* 99}$ 。のうち、中国福建省産の輝緑凝灰岩製石棺 は 1 号から 4 号である。石棺の表現の不鮮明な輪郭を把握する目的 で、写真から描きおこした図に画像処理を行い、写真による歪みを

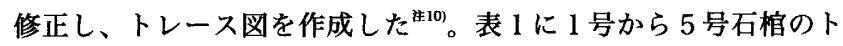
レース図一覧を示し、順に石棺の棺身の概要を述べる。

1号石棺の規模は他の石棺と比較して大きい。四隅に柱が表現さ れているが、組物などの表現はみられない。柱は丸柱で、噈盤の表 現は張り出しが小さい。柱頭にも装飾がみられる。また、柱には浮 き彫りが全体に施されている。

2号石棺と 3 号石棺では、四隅の柱から聥肘木とみられる部材が 梁、桁のそれぞれの方向に彫られており、二手先とみられる表現と なっている。四隅の柱は全て丸柱で、柱には浮き彫りが全体に施 されている。柱の浮き彫りは 2 号と 3 号では一致する部分もあるが、 細部に違いがみられる。礎盤は張り出しが小さい表現である。組物 は 2 号石棺も 3 号石棺のいずれも四面全てにみられる。

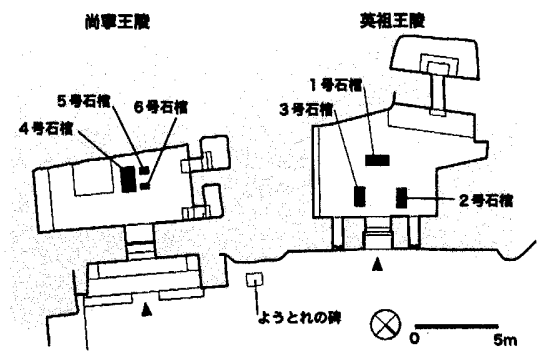

図 1 浦添ようどれ墓室平面と石棺の配置
4 号石棺には、四隅の柱と頭貫が表現されるが、組物の表現はな い。柱頭にも装飾がみられる。柱は丸柱で、柱には浮き彫りが全体 に施されている。礎盤は張出が小さい表現である。

5号石棺は、四隅に明らかに組物と考えられる突起が表現されて いる。調查時の観察と写真記録では突起部の細部が摩耗し、不鮮明 であったため、トレース図では1972年の調查記録図面と比較し組 物の形態を復元している。組物は木鼻、大斗、时木などが表現され ている。桁行方向、梁行方向共に肘木と时木の材端が柱の上部から 突出している。

6号石棺は、最も小さい。装飾も屋根に施された線刻のみで、建 築的な表現が最も少ない。屋根は宝形造で、軒には部材を示す表現 はみられない。調査時には屋根の四隅が欠損していたが、1972年 の記録では四隅に装飾が存在している。

次に、組物の表現に着目し比較分析を行い、表現対象について考 察を行った。 5 号石棺だけが四隅の柱の上に組物があり、部材が析 行方向と梁行方向に突出した表現がされている。組物は、桁を柱位 置から離し、屋根の軒の出を深くする機能を持つ。5号石棺はこの 観点から、当初から屋根を持つ建物を模していたと考えられる。法 隆寺玉虫㴻子をはじめとして、仏堂に建物の㱚形を置くことは古代 からみられた形式であるが、特に内陣に須弥增を置き、壇上に大型 の仏像を納めた厨子を備える形式は長保寺など室町時代の仏堂に多 くみられる’11。こうした屍子は入母屋造の屋根を持つことが多く、 正面に両開きの扉を持つが、5号石棺の表現と一致する。 5 号石棺 は仏舎利や仏像を納める尉子として意識されていたと考えられる。

2 号と 3 号石棺にも組物は表現されているが、軒を出し桁を受け る表現ではない。1号、4号石棺に組物の表現はみられず、柱と整 盤以外の建築部材表現としては、4 号石棺の頭貫とみられる表現だ けである。このような構造であっても屋根をかけることは不可能で はなく、部材の表現が省略されていると考えることもできる。しか 
し、礎盤、柱頭の部材は十分に意識されており、他の彫刻表現も粗 雑ではなく、技術的な理由から省略されたとは考えにくい。

3 号石棺の頭貫は仏像周辺の表現と干渉しあっており、当初から 建築部材が表現されていたものではない可能性がある。この点で 3 号石棺は 4 号石棺とほぼ同形式といえる。四方を装飾された柱で囲 まれ、仏像が並ぶ空間として、最も適当なものは建物そのものでは ないと考えたほうがよい。該当する空間として、仏堂内部または塔 の内部の四天柱とそこに安置された仏像が挙げられ、特に一間四面 堂に相当する可能性がある ${ }^{\star 12}$ 。代表的な一間四面堂として中尊寺 金色堂(1124年)が挙げられ、一間四方の母屋に仏壇が設けられる。 平面は正方形で宝形造の屋根となり。12世紀から13世紀にも各地 で同様の仏堂は建築されている。母屋に直接屋根がかけられること は違和感が残るが、中尊寺金色堂においても母屋部分だけにかかる 切妻屋根はあり、さらに宝形造の屋根に覆われていることから、屋 根は一重とは限らない。これらのことから、石棺は建築の外観を模 しているのではなく、仏堂や塔の内部を表していると考えられない だろうか。

組物の表現から、 5 号石棺は仏堂内部の厨子または仏堂、1 号か ら4号石棺は仏堂の母屋をそれぞれ表現しており、異なる意図のも とに製作されたと考えられる。

6 号石棺の棺身には、建築的な構造部材が認められない。石材の 色調と表現の独自性から、この石棺に関しては棺身と屋根は一体の ものと判断できる。屋根は、調查時には欠損していたが、1972年 の実測図ではわずかに四隅末端に装飾的な突起を持ち、宝形造であ つたことがわかる。18世紀の首里城での儀礼を描く史料には、宝 形造の屋根を持つ宣読台が描かれるほか、仮設の宴席も宝形造に描 かれ、権威を示す形態とみなされていたものであろう望13)。

\section{2-3. 浦添ようどれの石棺の建築表現による縓年}

石棺の屋根に表現された瓦による分析や、彫刻表現と技法に関し て台座を含めた分析による編年は行われており、首里城正殿の瓦苜 化など建築的な変化との対応関係の可能性も指摘されている しかしながら、製作時からの表現が最も多く含まれると考えられる、 棺身の建築表現による編年は行われていない。

浦添ようどれには、製作年代の判明している石棺はない。このた め、他の輝緑凝灰岩製石棺として知られている玉陵の石棺四基、小 禄墓の石棺一基、伊是名玉御殿の石棺二基と建築表現を比較するこ とにしたい。特に小禄墓石棺は輝緑凝灰岩製石棺のなかで唯一1494

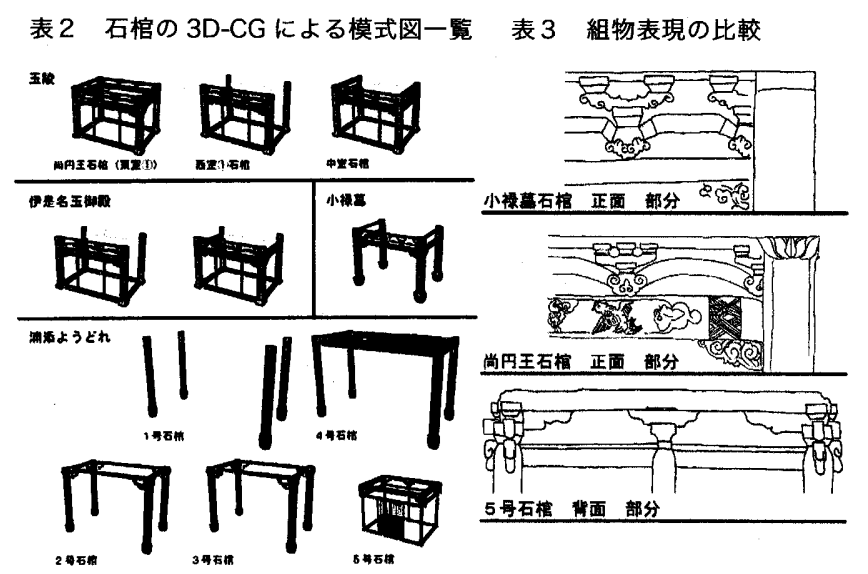

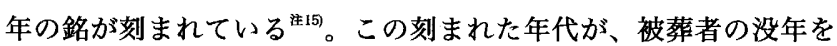
示すだけのもので、石棺は後世に作成された可能性もあるが、製作 と銘の差は数年程度だと仮定し話を進めたい。

棺身のみの建築表現を対象とし、石棺の表現を理解し着眼点を見 いだす目的で、主な石棺について史料から把握できる建築部材のみ を模式化し 3D-CGを作成したところ、小禄墓石棺と 5 号石棺に共 通点が認められた。石棺の3D-CGによる模式図一覧は表 2 に示す楀の。 小禄墓石棺は四隅の柱上部に突出した組物表現は持たないが、前 面に連続する装飾的な組物が表現されている。 5 号石棺では背面の 柱の上にも斗と実肘木とみられる部材がある。小禄墓石棺と 5 号石 棺は、頭貫または貫の上に組物があり、桁が表現される点が共通し ている。また、小禄墓石棺と玉陵の四基と伊是名玉御殿の二基は、 正面の貫の上に連続する組物や、側面に木鼻が表現されている点が 共通している。しかし、これら六基はいずれも角柱であることや、 正面に並ぶ組物の数が小禄墓とは異なる。

そこで、玉陵と伊是名玉御殿の石棺六基のなかでは四面すべての 写真が確認できた尚円王石棺を対象として比較する。5 号石棺、小 禄墓石棺と尚円王石棺に共通する通肘木を受ける組物に着目し、卜 レース図を表 3 に示す。 5 号石棺背面中央には実肘木とみられる組 物が表されている。小禄墓石棺正面の組物は双斗の时木に装飾のあ る表現がされている。これに対して尚円王石棺では正面の平三斗を 受ける束が左右に装飾を広げている。このように装飾的な部分であ りながら、いずれも本幕股の表現はみられない。本蟇股の普及が主 に鎌倉時代とされ、南北朝時代からは双斗、花肘木几と移行する日 本の寺院にみられる新和様の変化に対応すると考兄られ清而、判明 している小禄墓石棺の年代にもほぼ合致する。3つの石棺の製作は 5 号石棺、小禄墓石棺、尚円王石棺の順といえる。

5 号石棺が 1 号から 4 号石棺より建築表現として新しいことは、 複雑な組物などの部材表現から明確である。2号石棺は当初から組 物が表現されていたと考えられることから、1 号石棺から 4 号石棺 のなかでは最も新しいといえ、柱のみが表現されている 1 号石棺を 最も古いと考えることが妥当ではある゙

3 号石棺は 2 号石棺との共通点が多く、前後して製作されている といえる。4 号石棺は頭貫の表現以外は 1 号石棺との類似点が多く、 これが 2 号と 3 号石棺以降に製作されているとは考え難い。

以上の建築表現の比較から、浦添ようどれの石棺は 1 号、4 号、 3 号、 2 号の順で製作された後、 5 号石棺が1494年以前に製作さ れ、その後 6 号石棺が製作されたと考えられる。

\section{3. 浦添ようどれの変层と石棺の関係}

\section{3-1. 石棺の目罯の変遂}

1 号から 4 号石棺正面には建築表現のほかに、3 体から 5 体の像 が彫刻されている。浦添ようどれ全体の変遷を明らかにするにあた り、石棺の、現在の配置が当初からの製作意図に従ったものである かを知るには彫刻表現全体に着目する必要がある。

向かい合わせに配置され、建築表現にも共通点が多い 2 号石棺と 3 号石棺を比較すると、向かい合う面に二体の地蔵菩薩とされる僧 形の像、反対側に三体の像が表現されている。1 号石棺と、2 号、 3 号石棺で囲まれた空間が墓室の中心的な場所であると考えてよい ことから、2号と 3 号石棺は地蔵菩薩とされる像を正面として配置 
されている。しかし、1 号石棺では地蔵菩薩とされる像は背面で、 正面には阿弥陀三尊像とされる三体の仏像と、左右に二体の彫刻が みられる。2 号、3 号石棺の、背面として配置されている面には、 中央に円環状の光背と螺髪の頭部、白豪が表現された像と、左右に 頭部に装飾を持ち、持物のある像が表されており、これらも仏像と 考えられ、製作意図としての正面が現在は背面となっていといえる。 したがって、2 号と 3 号石棺は製作時とは配置が異なると考えられ る。また、 4 号石棺内の布が15世紀の製作、石積の整備と木棺の 金具などの廃棄の時期が 14 世紀後半から 15 世紀前半とされ 号石棺の製作が最も近い。2 号石棺が整備に際して、3 号石棺に即 して製作されたものなのか、建物と唐樌型木棺の廃棄以前に製作さ れていたものかを確かめる手段は乏しい。とはいえ、英祖王陵内で は 2 号石棺が、現在の配置への整備がなされた時期に最も近い製作 であることはいえよう。

さらに仏像の表現に着目すると、1 号と 4 号石棺では中央に三体 の仏像がそれぞれ蓮の花の上に表現されており、両端にひとつずつ 像が表現されている。1 号と 4 号石棺で表現が共通している像は左 端の像で、両手を胸の前で合わせ棒状の持物を水平に捧げている。 合掌した姿で、剣などを水平に構える表現は韋駄天を表すものであ

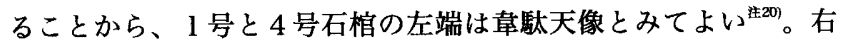
端の像はそれぞれの石棺で異なる表現がされており、1 号石棺では 右手に剣を持ち、左手を前に向けて開いて添えているが、4号石棺 では右手に宝塔を揭げ、左手で槍を持つ。4 号石棺の像の特徴は、 多聞天または毘沙門天に相当し、単独であることから昆沙門天と考 えてよいだろう。1 号石棺が、4号石棺と同様の意図を持って製作 されていたならば、多聞天または昆沙門天が表現されていると考元 られるが、特徴は異なっている。そこで、現存している他の四天王 像と比較したところ、戒壇院罒子扉の多聞天 ${ }^{\text {\#21) }}$ の、右手に剣を持 ち、左手を手前に向けて広げて添える表現が一致する。よって、1 号と 4 号石棺の右端は毘沙門天像と考えられる年22)。

四天王像は仏堂の四方の守護として、それぞれが対応する方角に 配置される。また、朝鮮半島には対応する方角に四天王像が彫刻さ れた石灯籠や石塔が多く現存している゙る゙。昆沙門天は北の守護と

され、像が北側に配置される意図で製作されたものであろう。4号 石棺では昆沙門天像が北に位置するよう配置されているが、1 号石 棺の配置では毘沙門天像が西に位置している。したがって、1 号石 棺は製作当初からの配置ではないと考えられる。

次に、 1 号から 4 号石棺に共通している中央の三体の仏像を比較 する。 2 号から 4 号石棺では、右側の像が右手に包子とみられる房 状の持物を、左手に椿を持つことが共通しているが、1 号石棺の中 央右側の像は両手で荎の長い蓮の蕾を持つ。4号石棺の中央左側の 像は損傷が激しいが、棒状のものを持つことがわかり、 2 号と 3 号 石棺の左側の像は茎の長い蓮の蕾を持つことが共通するが、1 号石 棺中央左側の像の右手付近に水瓶の輪郭をみることができる。2 号 から 4 号石棺の三体の仏像には細部の表現に違いはあるが共通点が 多く、1 号石棺の独立性が高いことがわかる。

石棺の規模や、韋䭾天と毘沙門天が両端に表現される形式は 1 号 と 4 号石棺で共通しており、制作意図に共通点があったことが䁈わ れる。しかし、毘沙門天の表現が異なり、韋駄天の持物が 1 号石棺 では剣、4号石棺では宝棒の表現である点が異なり、それぞれに表
現の根拠が存在したものだろう蜶。

また、4 号石棺にみられる、毘沙門天が持つ塔は石棺以外で唯一、 同時代の建築を示す史料として着目すべきである。極端に反りのあ る屋根の頂部に装飾があり、塔身が俺腹とみられる曲線で表現され た宝塔の形式で、方形の基壇上に表現されている。日本に現存する 宝塔としては性海寺のものが鎌倉時代の様式とされており、須弥壇 上に安置されている。多聞天像または毘沙門天像の持物の塔が宝塔 である事例として、法隆寺大講堂多聞天像などが知られており、10 世紀ごろの製作とされる。宝塔と多聞天像や毘沙門天像との関連付 けが、現存する主な宝塔の建築年代が鎌倉時代から室町時代までが 中心であったことと一致すると明確な判断はできないが、仏像と関 連付けられる建築表現も、石棺の製作年代を明らかにする大きな手 がかりとなりえる。英祖王の没年は1299年と伝えられており、日 本に現存する宝塔の多くが製作された時代から大きく隔たってはい ない ${ }^{\text {(25) }}$

以上で述べたように、像の表現からは 1 号石棺が 2 号から 4 号石 棺とは别に製作されたといえるが、英祖王陵では 1 号から 3 号石棺 が一組として配置されている。その配置も、製作された時点での正 面が意識された配置とは考えにくい。これらの実態から、石棺は製 作と配置が別に行われたと指摘できそうである。

石棺の配置の変化は、墓室の変遷と無縁ではないだろう。二つの 墓室の平面を図 1 に示したが、彫刻表現の意図する方角に即して配 置されている 4 号石棺の前には、白石の履子が設置されていたごく 低い土の壇がある。現在の墓室の構成として、東側が正面として整 備されているといえそうであるが、入口は北側に開かれている。英 祖王陵の入口も北に向かって開かれており、1号石棺の正面も北に 向けられ。二つの墓室の正面はどちらも入口のある北側とされるが、 イチ(池)と呼ばれる副室の入口が開く方向が異なっている。同様に 副室を持つ玉陵と比較すると、東室では規模が小さい副室の入口は 墓室の正面と同じ方向に開き、英祖王陵の状況と一致している。尚 寧王陵の副窒の入口は、 4 号石棺の正面と同じ方向に向けて開いて おり、墓室の正面は入口のある北側ではなく、東側だと考えること ができるから、4号石棺はやはり製作当初から尚寧王陵に配置され ていたと考えてよいだろゔ。

現在の配置に石棺が置かれた時期は、2 号と 3 号石棺が礎石と干 涉する位置にあるため、礎石の上の建物が廃棄された後である。廃 棄された瓦の周辺から発掘された金具などから、王陵内の建物と同 時期に唐檟型木棺が存在したと考兄られており、石棺の製作時期に も考慮しなくてはならない。しかし、4号石棺について述べたとお り、石棺が尚寧王陵に設置されていたとすれば、石棺と王陵内の建 物や木棺は排他的な存在ではない。英祖王陵内の石棺が現在の配置 となった時期が王陵内建物と木棺の廃棄後だとしても、石棺の製作 時期とは別に考劣る必要があるだろう。

\section{3-2、浦添ようどれの変是}

石棺が製作時から配置に変化があったとすれば、浦添ようどれ全 体の整備を反映していると考えられる。大規模な整備が行われた時 期と、整備の内容から浦添ようどれの変遷を把握することができる だろうか。

礎石は現在の壁の下にあることから、王陵内の礎石建物が存在し 
ていた状態では前面は開けられていたといえる。この建物の礎石の 下に粗い栗石が詰められていることを調査時に確認したが、これは 建築当初から相当の加重がかかることが想定されていたはずで、建 物の屋根は当初から瓦莫であったと考えられる。

英祖王陵内に瓦草屋根の建物が存在していた際、前庭を囲む瞥壁 も並存していたかどうかを検証する必要がある。庭を囲む鮆壁が設 けられている王陵としては玉陵が挙げられる。玉陵の造営は1501 年であることが、玉陵前の石碑に記されており、瓦苜屋根の建物が 存在した時期より後である。そこで、玉陵以前の王陵である、第一 尚氏の墓所といわれる天山陵、第一尚氏初代の尚巴志の父の墓と伝 えられる佐敷ようどれ、第一尚氏以前からの北山監守の墓とされる 今帰仁百按司墓を比較対象とする。

佐敷ようどれは18世紀に現在の場所に移設されたことが知られ ており、本来は佐敷グスクの崖下に造営されたことが伝えられてい る。正確な位置は不明であるが、崩落したとされる場所は周辺の平 地から非常によく見えることを調査時に確認した。同様に、浦添よ うどれの位置も浦添グスクの崖下であり、牧港湾からよく見える位 置にあり、前庭から市街地と湾が一望できる立地であると考えられ る。

佐敷ようどれより古いとされる今帰仁百按司墓は、現在では樹木 に覆われて前面が見通せないが、樹木の間から、運天港を見渡せる 位置にある。崖に開いた穴が墓室として使用され、前面は当初から 覆われておらず、現在の塀は近代以降の造作であることが知られて いる。

天山陵は第二次世界大戦中に破壊されており全貌は明らかではな いが、開けた場所に面していない。比較対象とした王陵のうち、玉 陵と最も造営時期が近いものは第一尚氏の王陵であった天山陵であ り、天山陵造営時期の前後で王陵の形式に変化があったことが窺わ れる。瓦惪屋根建物が存在した時期の英祖王陵は、開けた見通しの よい場所に設けられる形式の王陵の年代に属しており、現在のよう な檣壁は設けられていないと考えてよい。したがって、英祖王陵に 石棺が配置された際、同時に前面が壁で覆われたとは考えにくい。 壁と、2 号と 3 号石棺の位置に着目すると、入口の開口部は 1 号石 棺の正面ほぼ中央に向けて開かれ、2号と 3 号石棺の彫刻もよく見 えるように配置されていながら、壁側の面は䧓刻の確認が難しいほ ど接近しており、不自然といえる。この実態から、石棺が配置され た当初は前面が壁で覆われていなかったと考えられる。

浦添ようどれ全体が辐壁で囲まれる以前の英祖王陵の変遷をまと めると、(1)瓦草屋根の建物が存在し前面が開けていた時期、(2)瓦直 屋根の建物が廃棄され石棺が配置され前面が開けていた時期、(3)墓 室入口が壁で覆われた時期に分けることができる。

浦添ようどれに残る石碑には、尚寧王が英祖王の後継者として父 祖の墓を浦添ようどれに整備したことが記されている。尚寧王の父 と祖父の石棺は白石の㴻子のひとつと伝えられており、尚寧王陵の 整備は尚寧王の存命中であると考えてよい。尚寧王は生年が 1564 年、在位は1588年から 1620年に没するまでであるから、英祖王陵 の建物の破棄と石棺の配置時期は尚寧王の時代ではない。可能性が あるのは、英祖王陵の入口を壁で塞ぐ事、全体を踾壁で围む事であ る。玉陵の石棺も含めて、尚寧王の前後の時代に製作されている石 棺はすべて石灰岩製の小型石棺であり、写真から判断する限りでは
尚寧王陵内の白石の㴻子が最も製作年代が近いといえる。碑文がよ うどれ全体に言及していること、16世紀末に倭冦に備えたとされ る石牆が首里城に築かれていること、伊是名玉御殿が石積に改修さ れた時期が1688年とされていることから、浦添ようどれ全体を筒 壁で囲むと同時に、英祖王陵入口を壁で塞ぐ整備が、尚寧王の時代 のものと考えられる。

また、尚寧王の時代以降に、改修や補修が行われた可能性も考元 られる。1700年に今㛿仁グスク崖下にあったと伝えられる北山監 守の墓である大北幕(うーにしばか)が崖の崩落により現在地に移設 され、佐敷ようどれの移設が1764年と記録されている。これらの 墓の移設は第二尚氏の王たちにより、国家事業としてなされたこと が記録されている新。18世紀ごろに製作年代が最も近いと考えら れる石棺は 6 号石棺であり、全国的な整備事業のなかで尚寧王陵に 加えられた可能性が指摘できる。

\section{4. 英祖王陵内瓦㯰屋根建物の復元}

石棺の建築表現の分析であきらかなように、組物などの建築技法 は日本との関係が深いことがいえるだろう。棺身の仏像も日本での 阿弥陀信仰との関連が窺え、特に韋駄天像の表現は日本で知られて いる形式に従っている。石棺の材料が中国福建省産であることや、 発掘された瓦が高麗の形式であることが知られているが、建物の構 造はむしろ日本の形式に近似していると考えてょいのではないか。

英祖王陵内の礎石の実測からは、礎石の中心間の距離は7尺から 8尺の間で一定しないことがわかる。柱心が礎石中心に一致しなく てもよいと考えて、一間を7尺として復元を試みる。この場合、柱 は直径が六寸程度であれば礎石に収まる。棟は墓室の高さで規定さ れるから、最も高いところで約 $3 \mathrm{~m}$ とる。屋根は礎石と壁の位置 関係から平入切妻と考えることが自然であり、軒の出は、背面の岩 壁との距離で規定される。

重量のある瓦屋根を維持できる構造を備えていなくてはならない ため、仮設的な覆屋ではないといえる。1 号から 4 号の石棺が併存 していた可能性があること、石棺の彫刻の特徴から、墓室内建物に は鎌倉時代以前の様式が用いられていたと推測することができる。

以上のことから考えて、建物は、二間二間の方形平面で、柱間7 尺、棟高約 $3 \mathrm{~m}$ 、本瓦荤、平入切妻屋根で、このような特徵を備え た13世紀ごろまでの事例をもとに復元案を作成することは可能で あろう。図 2 に英祖王陵内の礎石概形と柱の配置を示す。

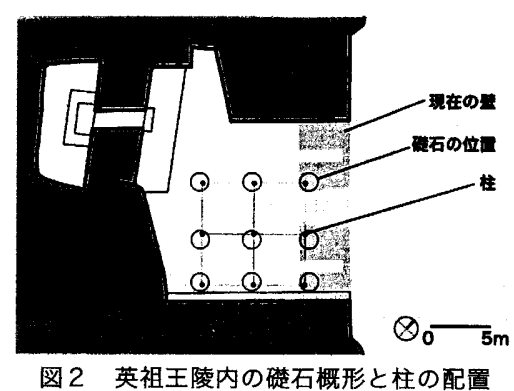

\section{5. 結論}

浦添ようどれの四基の輝緑凝灰岩製大型石棺と二基の小型石棺の 編年の結果、浦添ようどれの石棺棺身は 1 号、 4 号、3 号、2 号、 
5 号、6 号の順で製作されたと考えられる。組物の表現や、仏像の 特徴など、1 号から 4 号石棺には鎌倉時代の日本の事例と共通する 表現が多くみられる。仏像表現の比較からは、根拠がそれぞれ別に 求められていたことが窅われ、高い関心が持たれていたと思われる。

1 号から 4 号石棺は、以降に製作された石棺とは模した対象が異 なり、その製作意図の違いから第二尚氏の時代に製作されたとは考 えにくい。英祖王陵内建物の廃棄と石棺の配置も、第一尚氏以前に 行われた整備といえるが、石棺が製作された時代の王は不明である。 浦添ようどれは英祖王の造営と伝えられるが、王統の血緑関係は幾 度か断絶していることが明らかになっているき28)。にもかかわらず、 第二尚氏の時代にも英祖王の墓所として祀られ続け、王の尊称にも 英祖王の名が揭げられ 、琉球王朝と王権のあり方に大きな位置 を占めていたといえようき”

建築表現や仏像の表現からは、推測される製作年代における日本 では最先端の意匠が採用されており、石棺が製作された時代に琉球 王国が備えていた影響力や文化的地位は、従来から知られている明 との冊封体制だけで説明しきれるものではない。1 号から 4 号の石 棺の具体的な製作年代や製作者を特定するには、石棺そのものが最 も情報量が多く、確実な史料であり、棺身に彫刻された仏像に関し てもより詳細な検討が必要と考える。

石棺には、材料の輝緑凝灰岩が中国産であることなど、中国から の影響が大きく指摘されている。高麗系の瓦や、石造寺院施設との 類似性から、朝鮮半島の影響を無視することもできない。しかし、 組物などの建築表現からは、むしろ主に日本との関係が深く、日本 での建築様式の変化に対応していると考えられる表現があることが 明らかとなった。琉球の貿易中継国としての繁栄は、特定の一力国、 一地域だけとの関係で説明できるものではなく、建築についてもよ り広い範囲からの影響を想定した考察が必要であると考える。

謝辞 浦添市教育委員会文化課の安里進氏には調査の機会のみなら ず、王陵の変遷などについて多大なご示唆を頂きました。浦添市教 育委員会文化課の皆様にもお世話になりました。実測調查に際して は玉井哲雄先生、揚村固先生ほか、千葉大学玉井研究室 $\mathrm{OB}$ の前原 信達氏、松鵜秀也氏にご協力いただきました。いずれも、深く感謝 いたします。

注

注 1)この他に白石の厥子と呼ばれる数基の石桘が存在したが、損傷が激し く、調查時には撤去されており調査していない。

注 2) 浦添市教育委員会：蘇る琉球国中山王陵浦添ようどれ 2000.10 收 定 2002.3

注 3) 2003 年 9 月 17 日の千葉大学玉井研究室の調查に参加し、2004 年 3 月 19 日〜20日の浦添市教育委員会文化課巡検に参加したものである。

注 4) 又吉真三：浦添世清(ようとれ)陵総合調査 沖䋥県教育庁文化課蔵 1973.6

注 5) 文化財建造物保存技術協会編：重要文化財玉陵復原修理工事報告書 重要文化財玉陵復原修理委員会 1978.9

注 6) 稲葉和也 : 古代中国建築の木構造の成立過程について（漢代建築の復 原的研究一その 8) 日本建築学会大会学術講演梗概集 建築歴史. 意匠 pp.1969 1970 1980.9

注 7) 小林孝二、遠藤 明久：松前家藩公墓所石造屋形について 日本建築 学会大会学術講演梗概集 pp.2203 2204 1981.9

注 8) 浦添市教育委員会文化課：浦添ようどれ見学会パンフレット 2002.8
注 9) 浦添世㳻(ようとれ)陵総合調查 前揭史料と、実測調查結果から作成 した。図 2 も同椂。

注 10） 4 号石棺右下は手前に 5 号石棺があり適当な写真が得られていない。 その他、写真撮影が困難な面、損傷により輪郭線を検出することが 困難であった面の図は省略した。

注 11）太田博太郎編：日本建築史基礎資料集成四仏堂 I 中央公論美術出 版社 1981.1

注 12) 山岸常人：中世寺院社会と仏堂 塙書房 1990.2 富貴寺大堂床 下の大石と穴から、墓堂であった可能性が指摘されている。中尊寺 金色堂と同時期の一間四面堂としては、願成寺阿弥陀堂(1160 年)、 高藏寺阿弥陀堂(1177 年)などが知られている。

注 13) 鎌倉芳太郎：沖縄文化の至宝(二分冊) 岩波書店 1982.10 「首 里城 正殿前城元仲秋宴設営絵図」と「首里城 正殿前城元設営図」

注 14）上原靜: 輝緑岩製石棺にみる屋根瓦 琉球・東アジアの人と文化 高 宮廣衛先生古希記念論集 上巻 pp.315 342 高宮廣衛先生古希 記念論文集刊行会 2000.10

注 15) 沖縄県教育委員会：沖縄の文化剘 III 沖縄県立博物館友の会 1997.6 「弘治七年 おろく大やくもい 六月吉日」の銘がある。 弘治七年は 1494 年にあたる。

注 16) 南風原町 (沖縄県)、那霸出版社 : 沖縄文化財百科 第一巻 建造 物・美術工芸 那羁出版社 1988.5 小禄墓石棺側面の写真を確認 した。なお、未確認の面の部材は薄く表示している。

注 17) 伊藤延男、小林剛：中世寺院と鎌倉䧓刻 原色日本の美術 9 小学 館 1968.

注 18) 又吉真三氏の調查記録から棺身柱芯間の長辺と短辺の比を求めたと ころ、1 号石棺から順に $1: 2.1 、 1: 2 、 1: 2 、 1: 2.24 、 1: 1.36$ である。 製作年代が新しいほど両柱間の差が小さくなる傾向にあるとすれば、 1 号と 4 号は逆軽している。

注 19）浦添市教育委員会：浦添ようどれ I 石積遺構編-史跡浦添城跡整備事 業儿伴う発掘調查報告- 2001.3

浦添市教育委員会：ようどれ石屍子と遭骨の分析結果について 2003.6

注 20) 真鍋俊照編:日本仏像事典 吉川弘文館 2004.12 韋駄天は南方守 護の増長天配下で、日本では宝剣または宝棒を水平に構え合掌する 姿に造られ、鎌倉時代に中国から伝わったものとされる。伽藍の守 護、特に禅宗寺院の庫裡にまつられる。

注 21）水野敬三郎監：カラー版日本仏像史 美術出版社 2001.5 高山寺 旧藏、戒壇院欴子㗺絵四天王像の多聞天。

注 22) 錦織完介：天部の仏像事典 東京美術 1983.11 多聞天像、昆沙 門天像は塔を持つものが多いか゚、持物や形態は必ずしも一定しない。

注 23) 高裕炇 : 朝鮮荅婆の研究 吉川弘文館 1978.9

黄壽永編：韓国美術全集(日本語版) 6 石塔 同和出版公社 1974.7 日本語版 1974.11

仏教寺院伽藍の中心に木造建築を模した石造の塔婆(塔)が現存してお り、特に敬天寺十層石塔(14 世紀)、円党寺址十層石塔(朝鮮初期)など で仏像とともに屋根、瓦、組物、柱などの建築表現がみられる。

注 24) 久野健編：仏像集成 2 日本の仏像<中部> 学生社 1992.1 鎌倉 時代の作とされる乙津寺韋䭾天像の持物は宝棒である。

注 25) 太田博太郎編：日本建築史基碳資料集成十二塔婆 II 中央公論美術 出版社 1999.11

注 26) ただし、この時点での尚鼾王陵が現在と同じ状態であるかは不明。

注 27) 重要文化財玉陵復原修理工事報告書 前揭書

注 28) 原田禹雄：琉球と中国 忘れられた冊封使 吉川弘文館 2003.5

注 29) 外間守善校注：扔もろさうし 上、下 岩波書店 2000.11 「英

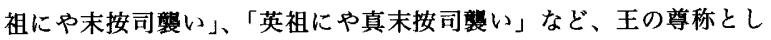
て英祖王の末裔であることを讃える表現が絽返し表れる。

注 30) 安里進 : 琉球王国の形成と東アジア 日本の時代史 18 琉球・沖縄 史の世界 吉川弘文館 pp.84 115 2003.11 英祖王は伝承とさ れることもあったが、発掘成果からは実在を認められるとされる。

（2005年 7 月 8 日原稿受理， 2005 年10月 31 日採用決定 